\title{
Nanoparticle-assisted photo-Fenton reaction for photo-decomposition of humic acid
}

\author{
Jhuma Banik ${ }^{1} \cdot$ Srijita Basumallick $^{1}$
}

Received: 19 June 2016/Accepted: 21 April 2017/Published online: 29 April 2017

(c) The Author(s) 2017. This article is an open access publication

\begin{abstract}
We report here the synthesis of CuO-doped $\mathrm{ZnO}$ composite nanomaterials (NMs) by chemical route and demonstrated for the first time that these NMs are efficient catalysts for $\mathrm{H}_{2} \mathrm{O}_{2}$-assisted photo-decomposition (photoFenton type catalyst) of humic acid, a natural pollutant of surface water by solar irradiation. This has been explained by faster electron transfer to $\mathrm{OH}$ radical at the $\mathrm{p}-\mathrm{n}$ heterojunction of this composite catalyst. Application of this composite catalyst in decomposing humus substances of local pond water by solar energy has been demonstrated.
\end{abstract}

Keywords Photo-Fenton reaction · Humic acid . $\mathrm{CuO}$-doped $\mathrm{ZnO}$ composite nanomaterials

\section{Introduction}

Humic substances (HS) are natural organic matter (NOM), present in water bodies like ponds, lakes and rivers. HS are formed mainly by bio-degradation of plants by the process of humification. They are complex, heterogeneous polydispersed mixtures of organic substances whose compositions are not yet clearly known (Piccolo 2002). HS is generally present at ppm level in pond water and a slight excess makes the water brownish. During chlorination of water in drinking water plant, HS are converted to carcinogenic chloro-compounds (Breider and Albers 2015; Basumallick and Santra 2017); hence, they must be removed before water treatment.

Srijita Basumallick

srijitabasumallick@gmail.com

1 Department of Chemistry, National Institute of Technology, Agartala 799046, India
Fenton (Fenton 1894) reagents are often used for decomposing organic pollutants from waste water. The reagent comprises of $\mathrm{H}_{2} \mathrm{O}_{2}$ and ferrous iron, and it generates hydroxyl radicals, which are reactive oxygen species (ROS) and oxidize organic pollutants including humic acid (Wang et al. 2012). The ferrous iron $\left(\mathrm{Fe}^{2+}\right)$ initiates and catalyzes the decomposition of $\mathrm{H}_{2} \mathrm{O}_{2}$, resulting in the generation of hydroxyl radicals. The generation of $\mathrm{OH}$ radicals involves a series of reactions in an aqueous solution. Thus, $\mathrm{H}_{2} \mathrm{O}_{2}$ acts as an initiator for the generation of $\mathrm{OH}$ radicals, but $\mathrm{OH}$ radicals so generated easily recombine to form $\mathrm{H}_{2} \mathrm{O}_{2}$ again (Ebrahiem et al. 2013). In general, Fenton's oxidation process is coupled with UV radiation to accelerate the decomposition of $\mathrm{H}_{2} \mathrm{O}_{2}$ to $\mathrm{OH}$ radicals and known as photo-Fenton process and the reagent (Ebrahiem et al. 2013) is designated as $\left(\mathrm{UV} / \mathrm{H}_{2} \mathrm{O}_{2} / \mathrm{Fe}^{2+}\right)$.

Recently, semiconductor photo-catalysts such as titanium oxide and zinc oxide have been applied for photodegradation of contaminants in waste water and air $(\mathrm{Fu}-$ jishima 1972; Amy et al. 1995; Hariharan 2006; Daneshvara et al. 2004). The photo-catalyst, $\mathrm{ZnO}$ has also been considered as a suitable alternative for $\mathrm{TiO}_{2}$, the most used and typical photo-catalytic material, due to their similar band-gap energies. Again, $\mathrm{ZnO}$ nanomaterials (NMs) are cost-effective, easily synthesized and environment friendly.

$\mathrm{H}_{2} \mathrm{O}_{2}$-assisted photo-Fenton reaction for the degradation of humic acid onto $\mathrm{ZnO}$ surface has been reported (Oskoeia et al. 2016). $\mathrm{ZnO}$ illuminated by UV, can photo-degrade humic acid by itself, presence of $\mathrm{H}_{2} \mathrm{O}_{2}$ enhances the degradation process (Oskoeia et al. 2016). But these processes use UV as a source of photo-illumination. This is costly and an energy-consuming process. We intend to use solar radiation for degradation of humic acid. We studied a similar reaction using $\mathrm{ZnO}$ nanoparticles illuminated by solar radiation at noon for three hours at our institute open 
space $\left(23.8315^{\circ} \mathrm{N}, 91.2868^{\circ} \mathrm{E}\right)$ utilizing UV from solar radiation at neutral $\mathrm{pH}$. We have noted considerable enhancement of the degradation process of humic acid by combined effect of $\mathrm{ZnO}$ and $\mathrm{H}_{2} \mathrm{O}_{2}$. We have extended our research by doping $\mathrm{ZnO}$ NPs with $\mathrm{CuO}$ by hydrothermal method to enhance their photo-catalytic efficiency (Saravanana et al. 2013; Chang et al. 2013), and tested the application of this composite catalyst for decomposition of humus substances of a local pond water.

\section{Materials and method}

$\mathrm{ZnO}$ nanopreparation: $\mathrm{ZnO} \mathrm{NMs}$ of average size $(50 \mathrm{~nm})$ have been prepared by simple literature protocol (Ghorbani et al. 2015) mixing dilutions $(0.1 \mathrm{M})$ of each of the solutions $\mathrm{Zn}\left(\mathrm{NO}_{3}\right)_{2}$ and $\mathrm{KOH}$ under vigorous stirring and calcined the washed precipitate at $50{ }^{\circ} \mathrm{C}$.

$\mathrm{CuO}$ nanopreparation on $\mathrm{ZnO}$ : the $\mathrm{NMs}$ so formed $(10 \mathrm{mg})$ were dispersed in $30 \mathrm{ml}$ of $0.01 \mathrm{M} \mathrm{CuSO}_{4}$ solution taken in a $100 \mathrm{ml}$ hydrothermal bomb, where a precipitate of $\mathrm{Cu}(\mathrm{OH})_{2}$ is formed by adding dilute $\mathrm{KOH}$ solution drop wise, and heated under hydrothermal condition at $80^{\circ} \mathrm{C}$ for $1 \mathrm{~h}$. The mixture was cooled, centrifuged and washed repeatedly with DI water, and dried under vacuum.

\section{Photo-degradation study}

The composite NMs were re-dispersed for characterization and photo-chemical studies. Photo-degradation study was carried out in a laboratory model photo-reactor, which is a simple glass vessel $(250 \mathrm{ml})$ with a glass lead and an orifice for release of any gaseous product. An aqueous solution $(150 \mathrm{ml})$ of sodium salt of humic acid (Loba Chemicals) at $\mathrm{ppm}$ concentration, mixed with $50 \mathrm{mg}$ of $\mathrm{ZnO} / \mathrm{ZnO}-\mathrm{CuO}$ catalysts was taken within the reactors and exposed to direct sunlight at noon for $3 \mathrm{~h}$. A similar setup was kept in dark. After each set of experiment the catalyst was recovered by leaching out the HA salt and reused for the next set. $\mathrm{ZnO}-\mathrm{CuO}$ composite has been used as UV sensor (Park et al. 2015) and reported as a photostable material.

After $3 \mathrm{~h}$ humic acid concentrations were monitored spectrophotometrically at an absorbance of $254 \mathrm{~nm}$.

\section{Results and discussions}

Figure 1 shows the UV-visible absorption spectra of very dilute dispersions of $\mathrm{ZnO}$ and $\mathrm{ZnO}$-composite NMs. A characteristic $\mathrm{ZnO}$ absorption peak at $367 \mathrm{~nm}$ (black line)

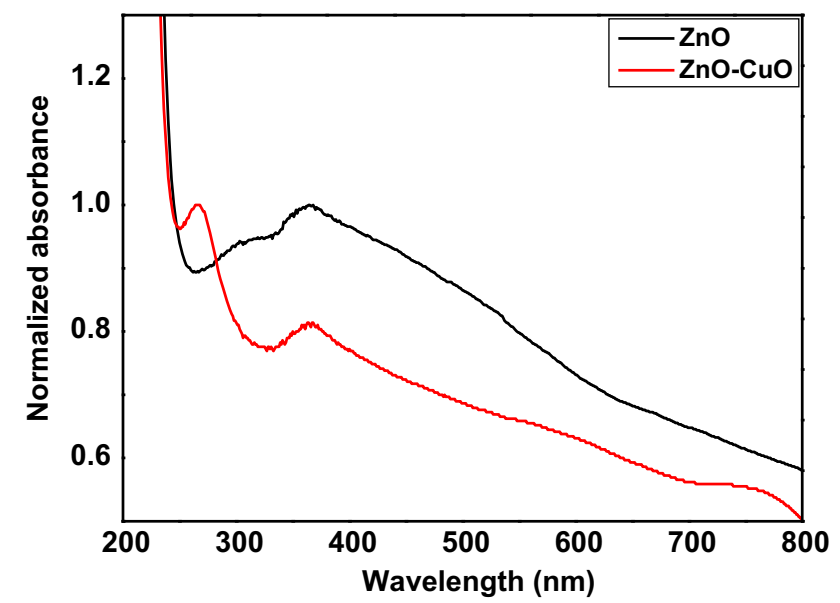

Fig. $1 \mathrm{UV}$-visible spectra of aqueous dispersions of $\mathrm{ZnO}$ (black line) and $\mathrm{ZnO}-\mathrm{CuO} \mathrm{NMs}$ (red line)

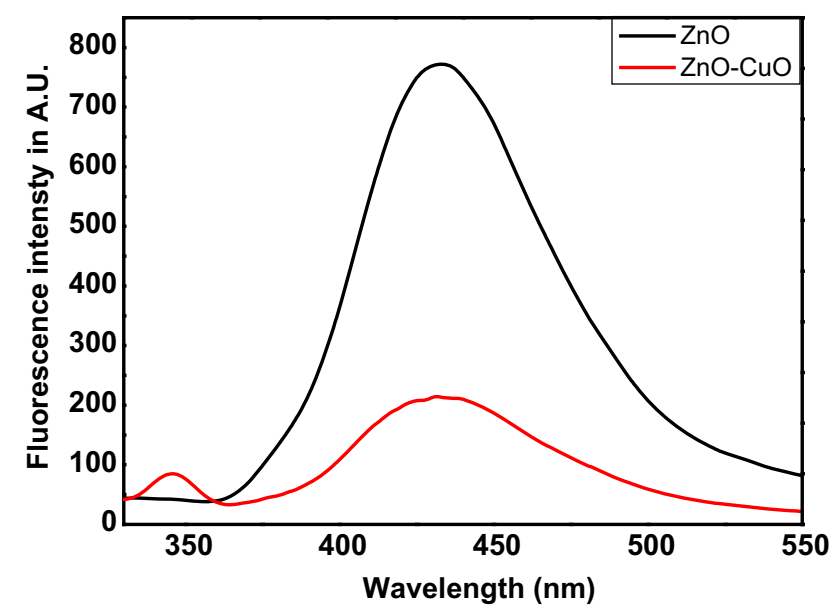

Fig. 2 Fluorescence spectra of aqueous dispersions of $\mathrm{ZnO}$ (black line) and $\mathrm{ZnO}-\mathrm{CuO} \mathrm{NMs}$ (red line)

is observed with $\mathrm{ZnO} \mathrm{NMs}$, while the composite shows an additional peak at $266 \mathrm{~nm}$ (red line) indicating the presence of $\mathrm{CuO}$.

The fluorescence spectra of prepared $\mathrm{ZnO} \mathrm{NMs}$ are shown in Fig. 2 (black line), a similar spectrum for the composite NMs is shown in red line. Observed quenching of $\mathrm{ZnO}$ fluorescence clearly indicates formation of composite NMs. XRD of the composite NM is shown in Fig. 3, which is similar to that of reported XRD data of $\mathrm{ZnO}$, but appearance of peaks at $38.8^{\circ}$ indicates the incorporation of $\mathrm{CuO}$ (Jai et al. 2012) within crystal structure of $\mathrm{ZnO}$. Close scrutiny of XRD image indicates slight shift of peak position of $\mathrm{ZnO}$ relative to JCPDS 8000-75 data, for instance the peak at 31.728(100) and 34.400(002) for pure $\mathrm{ZnO}$ are shifted to 31.6601 and 34.4201 , respectively . Similarly, peak at 38.736 for $\mathrm{CuO}$ (JCPDS 8019-17) is shifted to 38.8001 . This may be due to the formation of 


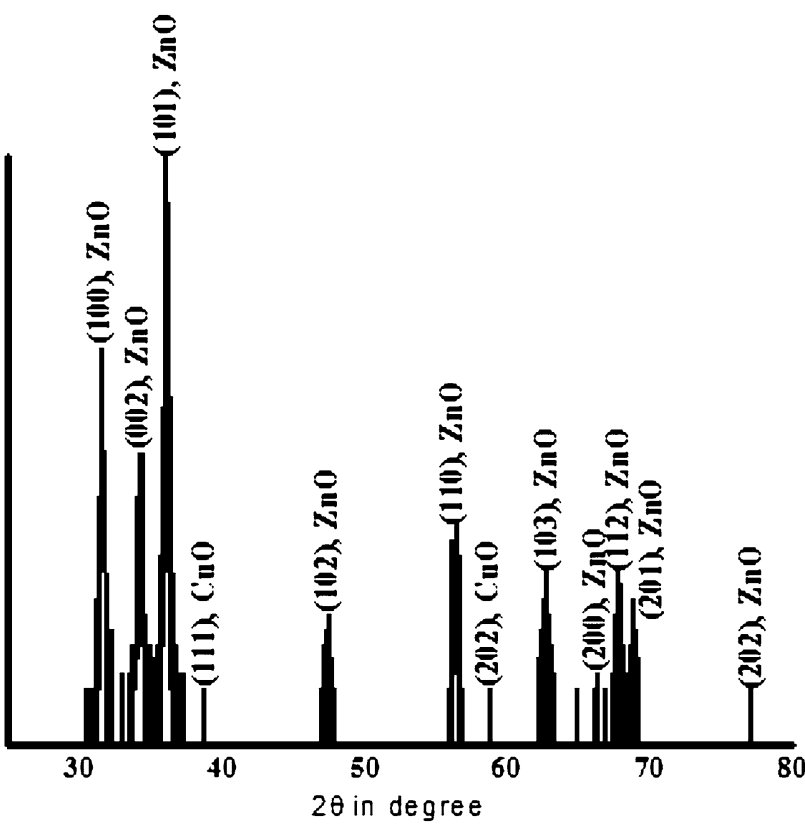

Fig. $3 \mathrm{XRD}$ of $\mathrm{ZnO}-\mathrm{CuO}$ nanocomposites

alloy-type composites of $\mathrm{ZnO}-\mathrm{CuO}$ as expected from the almost similar ionic radii of $\mathrm{Zn}^{2+}$ and $\mathrm{Cu}^{2+}$. Since peak intensities of $\mathrm{CuO}$ are small and associated with noise peaks, it is likely that wurtzite structure of $\mathrm{ZnO}$ with unit cell parameters $a=b=3.25 \mathrm{~A}$ and $c=5.21 \mathrm{~A}$ is almost retained in $\mathrm{ZnO}-\mathrm{CuO}$ composite.

SEM image of the composite $\mathrm{ZnO}-\mathrm{CuO}$ particle is shown in Fig. 4. It is seen that the particles are mostly rod shaped, approximately $50-200 \mathrm{~nm}$ in size, and mostly agglomerated.

Percentages of humic acid photo-chemically degraded (subtracting values for the dark reactions) are shown in the bar-diagram (Fig. 5). Figure 5 is self-explanatory, and

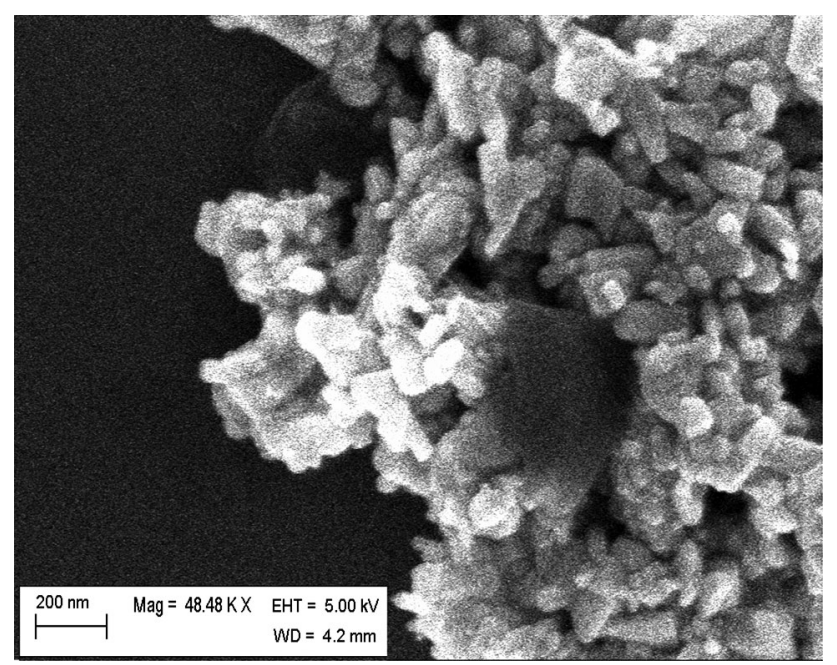

Fig. 4 SEM image of $\mathrm{ZnO}-\mathrm{CuO}$ composite particles

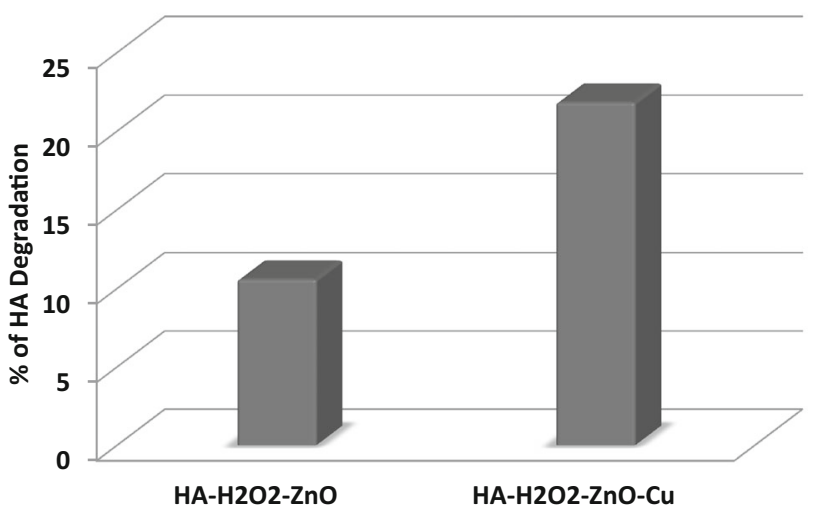

Fig. 5 Percentage of HA degraded by photo-Fenton type reactions under solar irradiation for $3 \mathrm{~h}$

suggests that $\mathrm{ZnO}-\mathrm{CuO}$ in the presence of $\mathrm{H}_{2} \mathrm{O}_{2}$ enhances photo-decomposition of humic acid under solar irradiation.

\section{Photo-degradation study of water sample collected from a local pond}

For this study, water samples from a local pond near our institute were collected in standard joint glass containers following literature protocol for such collections. The sample was filtered to remove any particles and allowed to stand for $12 \mathrm{~h}$ before the decanted sample was used for photo-decomposition study. The UV-visible spectra of the sample are shown (black line) in Fig. 6. The concentration of the HS present in the sample was measured by UVvisible spectra at $-254 \mathrm{~nm}$. The photo-decomposition study was carried out by the procedure stated above and UV-visible spectrum of the photo-catalytic decomposed solution is shown in Fig. 5 (red line).

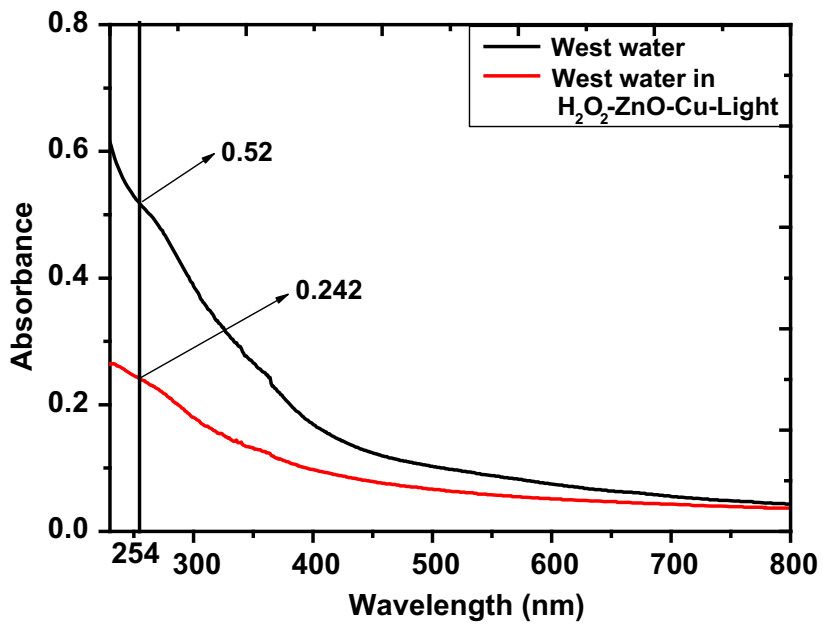

Fig. 6 Percentage of HA degraded by photo-Fenton type reactions under solar irradiation for $3 \mathrm{~h}$ in pond water 


\section{Proposed mechanism}

It is known (Guo et al. 2013) that ZnO NMs can produce ROS under UV illumination as the potential of photo-excited hole at the valence band $(2.6 \mathrm{~V}$ versus $\mathrm{NHE}$ at $\mathrm{pH} 7$ and $\mathrm{CB} \sim-0.5 \mathrm{~V}$ versus NHE) (Oda et al. 2014; Dai et al. $2015)$ is much above the $\mathrm{H}_{2} \mathrm{O}$ decomposition potential (1.48 versus $\mathrm{NHE}$ ). $\mathrm{H}_{2} \mathrm{O}_{2}$ photodecomposed to $\mathrm{OH}$ radicals, and this $\mathrm{OH}$ radical can easily accept electrons at the conduction band of $\mathrm{ZnO}$ forming $\mathrm{OH}^{-}$anion, similar to that of photo-Fenton reduction of $\mathrm{OH}$ by $\mathrm{Fe}^{2+}$ ion (Ebrahiem et al. 2013). Since $\mathrm{CuO}$ is a p-type semiconductor, it seems that electron transfer from $\mathrm{CB}$ of $\mathrm{ZnO}$ to $\mathrm{OH}$ at this heterojunction ( $\mathrm{Yu}$ et al. 2015) becomes faster, reducing radical $(\mathrm{OH})$ recombination reaction. The mechanism of HA degradation, as explained above, is pictorially shown below:

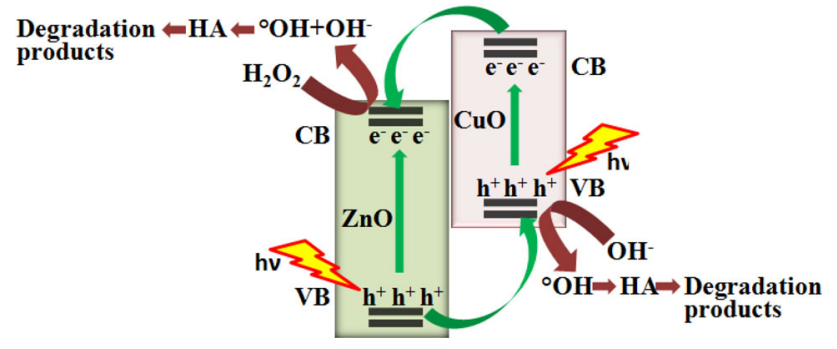

Once $\mathrm{OH}$ radicals are easily formed on the semiconductor surface they oxidize (Goldstone et al. 2002) the humic acids to different low-molecular weight organic acids like acetic, formic, malonic, and oxalic acid.

\section{Conclusions}

From this preliminary study, we have demonstrated that $\mathrm{ZnO}-\mathrm{CuO}$ composite NMs enhance Fenton-type photodecomposition of humic acid, a natural pollutant present in surface water, by $\mathrm{H}_{2} \mathrm{O}_{2}$ under solar irradiation and suggested that electron transfer from $\mathrm{CB}$ of $\mathrm{ZnO}$ in the $\mathrm{ZnO}-$ $\mathrm{CuO}$ nanocomposite becomes faster to $\mathrm{OH}$ radical because of the presence of $\mathrm{p}-\mathrm{n}$ hetero-junction at the composite NMs. When this composite catalyst is applied to study photo-decomposition of humus substances in local pond water, we observed a relative decomposition of humus substances to the extent of $53.5 \%$ in $3 \mathrm{~h}$ under mid-solar radiation (12.0-3.0 pm). From this preliminary study, we have demonstrated that $\mathrm{ZnO}-\mathrm{CuO}$ composite nanomaterials enhance Fenton-type photo-decomposition of humic acid by $\mathrm{H}_{2} \mathrm{O}_{2}$ under solar irradiation and have a good application potential.
Acknowledgements The authors are thankful to the Head of the Chemistry Department, NITA for providing necessary support for this research. The authors are thankful to the Reviewers for valuable comments and suggestions.

Open Access This article is distributed under the terms of the Creative Commons Attribution 4.0 International License (http:// creativecommons.org/licenses/by/4.0/), which permits unrestricted use, distribution, and reproduction in any medium, provided you give appropriate credit to the original author(s) and the source, provide a link to the Creative Commons license, and indicate if changes were made.

\section{References}

Amy LL, Lu G, Yates JT (1995) Photocatalysis on $\mathrm{TiO}_{2}$ surfaces: principles, mechanisms, and selected results. Chem Rev 95(3):735-758

Basumallick S, Santra S (2017) Monitoring of ppm level humic acid in surface water using $\mathrm{ZnO}$-chitosan nano-composite as fluorescence probe. Appl Water Res 7:1025-1031

Breider F, Albers CN (2015) Formation mechanisms of trichloromethyl-containing compounds in the terrestrial environment: a critical review. Chemosphere 119:145-154

Chang T, Li Z, Yun G, Jia Y, Yang H (2013) Enhanced photocatalytic activity of $\mathrm{ZnO} / \mathrm{CuO}$ nanocomposites synthesized by hydrothermal method. Nano Micro Lett 5(3):163-168

Dai C, Qing E, Li Y, Zhou Z, Yang C, Tian X, Wang Y (2015) Novel MoSe2 hierarchical microspheres for applications in visible-lightdriven advanced oxidation processes. Nanoscale 7:19970-19976

Daneshvara N, Salarib D, Khataeea AR (2004) Photocatalytic degradation of azo dye acid red 14 in water on $\mathrm{ZnO}$ as an alternative catalyst to $\mathrm{TiO}_{2}$. J Photochem Photobiol A Chem 162(2-3):317-322

Ebrahiem EE, Al-Maghrabi MN, Mobarki AR (2013) Removal of organic pollutants from industrial wastewater by applying photoFenton oxidation technology. Arab J Chem. doi:10.1016/j.arabjc. 2013.06.012

Fenton HJH (1894) Oxidation of tartaric acid in presence of iron. J Chem Soc Trans 65:899-910

Fujishima A (1972) Electrochemical photolysis of water at a semiconductor electrode. Nature 238:37-38

Ghorbani HR, Mehr FP, Pazoki H, Rahmani BM (2015) Synthesis of $\mathrm{ZnO}$ nanoparticles by precipitation method. Orient $\mathrm{J}$ Chem 31(2):1219-1221

Goldstone JV, Pullin MJ, Bertilsson S, Voelker BM (2002) Reactions of hydroxyl radical with humic substances: bleaching, mineralization, and production of bioavailable carbon substrates. Environ Sci Technol 36(3):364-372

Guo D, Bi H, Liu B, Wu Q, Wang D, Cui Y (2013) Reactive oxygen species-induced cytotoxic effects of zinc oxide nanoparticles in rat retinal ganglion cells. Toxicol In Vitro 27(2):731-738

Hariharan C (2006) Photocatalytic degradation of organic contaminants in water by $\mathrm{ZnO}$ nanoparticles: revisited. Appl Catal A Gen 304:55-61

Jai W, Dong H, Zaho J, Dang S, Zhang Z, Li T, Liu X, Xu B (2012) $\mathrm{Cu}_{2} \mathrm{O}$ p- $\mathrm{Cu}_{2} \mathrm{O} / \mathrm{n}-\mathrm{ZnO}$ heterojunction fabricated by hydrothermal method. Appl Phys A 109:751-756

Oda AM, Salih A, Hadi S, Jawad A, Sadoon A, Fahim Y, Fadhil A (2014) Photocatalytic decolorization of methylene blue dye by zinc oxide powder. J Babylon Univ Pure Appl Sci 22(9):2508-2515 
Oskoeia V, Dehghania MH, Nazmaraa S, Heibatia B, Asifd M, Tyagie I, Agarwale S, Guptae VK (2016) Removal of humic acid from aqueous solution using $\mathrm{UV} / \mathrm{ZnO}$ nano-photocatalysis and adsorption. J Mol Liq 213:374-380

Park YJ, Yang JH, Ryu BD, Cho J, Cuong TV, Hong CH (2015) Solution-processed multidimensional $\mathrm{ZnO} / \mathrm{CuO}$ heterojunction as ultraviolet sensing. Opt Mater Express 5(8):1752. doi:10. 1364/OME.5.001752

Piccolo A (2002) The supra molecular structure of humic substances: a novel understanding of Humus chemistry and implications in soil science. Adv Agron 75:57-134
Saravanana CR, Karthikeyanb S, Gupta VK, Sekaran G, Narayanane V, Stephena A (2013) Enhanced photocatalytic activity of $\mathrm{ZnO} /$ $\mathrm{CuO}$ nanocomposite for the degradation of textile dye on visible light illumination. Mater Sci Eng 33(1):91-98

Wang GS, Liao CH, Wu FJ (2012) Photodegradation of humic acids in the presence of hydrogen peroxide. Chemosphere 42(4):379-387

Yu J, Zhuang S, Xu X, Zhu W, Fenga B, Hu J (2015) Photogenerated electron reservoir in hetero-p- $\mathrm{n} \mathrm{CuO}-\mathrm{ZnO}$ nanocomposite device for visible-light-driven photocatalytic reduction of aqueous Cr(VI). J Mater Chem A 3:1199-1207 